\title{
Effects of Clinical Placements on Paramedic Students' Learning Outcomes
}

\author{
N Wongtongkam and L Brewster
}

\begin{abstract}
Background: Clinical placements are of major importance in students' learning processes through creating supportive environments and fostering independence into paramedic professional roles. The study aimed to explore whether clinical experiences in out-of-hospital emergency services affected students' learning outcomes and satisfaction.

Methods: A retrospective study was carried out using preceptors' evaluations $(n=160)$ and students' feedback forms ( $n=21)$. Descriptive and non-parametric inferential statistics were used to analyse quantitative items, and open-ended questions were analysed using content analysis.
\end{abstract}

Results: Findings showed that more than $70 \%$ of students were satisfied with the quality of preceptors and the fieldwork atmosphere. Preceptors reported that students' clinical skills across all categories improved significantly in the last two weeks of training. Qualitative data indicated that students displayed appropriate behaviour and professional socialisation and were keen to learn, and demonstrated competence in paramedic skills.

Conclusion: A supportive atmosphere and positive student-preceptor relationships are key attributes for clinical placements if students are to accomplish learning outcomes in out-ofhospital environments.

Key words: clinical placements; learning outcomes; New South Wales; paramedic; students.

\section{Nualnong Wongtongkam}

School of Biomedical Sciences,

Charles Sturt University,

Bathurst, NSW, Australia

\section{Lyle Brewster}

School of Biomedical Sciences,

Charles Sturt University,

Bathurst, NSW, Australia

\section{Correspondence:}

nwongtongkam@csu.edu.au

\section{Introduction}

A preceptor is defined as an experienced clinician who facilitates and fosters clinical learning skills, enhances competencies and builds confidence in students preparing for healthcare professions by direct involvement in the teaching and learning process in clinical settings. [1]

The preceptor role is multifaceted and complex [1] because he or she must align responsibilities for patient care with facilitation of student learning. Preceptors may experience stress and burnout [2] caused through increasing workloads and the need to protect their licence to practise from allegations of malpractice that may result from student errors. [3] Consequently, preceptors may not acknowledge students or involve them in the clinical team. Several studies have emphasised that working in supportive environments and developing good clinical skills and decision-making in patient care are important influences on students' decision to remain in healthcare professions. [4] Preceptor feedback contributes substantially to student achievement and improvement in their critical thinking skills. $[5,6]$

Additionally, students who regularly use feedback to improve their work are more likely to succeed as part of a clinical team and attain a level of independence in their clinical skills.

Paramedics work in ambulance services to provide care in critical issues or medical emergencies. An ambulance 
emergency call-out is multifaceted and has extraordinary challenges because paramedics manage a wide range of conditions in patients, from lifethreatening issues requiring immediate attention to those where no treatment is needed. Paramedics also encounter people from various age groups, cultures, and social backgrounds [7] and the services delivered to patients are significant for their wellbeing and recovery. [8]

Therefore, it is essential that undergraduate paramedic students gain hands-on skills through clinical placements in ambulance services so they can apply knowledge learned in the classroom to real life situations. It is essential that undergraduate paramedic students have opportunities to practise in clinical settings so they can integrate the clinical knowledge gained at university with emergency practices. The number of clinical placements hours required by universities varies and is inconsistent across programs and Australian states. In the authors' university, students are expected to spend 480 hours on placements with ambulance services and in community settings. [9] Second and third year paramedic students spend nearly 200 hours on placements a year (4-5 week). Clinical environments in ambulance settings are different from those in hospitals because paramedics must perform tasks quickly in difficult conditions and make rapid clinical judgements to save patients' lives at the scene. [5] Hence, the role of healthcare professionals in out-of-hospital settings is somewhat different from that of hospital emergency room staff. Although preceptors have similar roles across healthcare professions, paramedic professionals perform a diverse range of invasive procedures, some of which may be considered risky treatments. [10] Hence, paramedics require different clinical skills to those of nurses. While several studies have explored the relationship between clinical placements and aspects of student learning, most have emerged from nursing perspectives and there are few studies from the paramedic paradigm. [11]

Boyle and colleagues carried out a pilot study of paramedic students' experiences of clinical placements in Victoria and found that nearly $85 \%$ of participants mentioned that classroom scenarios helped them to understand real-time patients and approximately $90 \%$ gained handson practical experiences while working on the road. However, $69 \%$ of them believed they undertook unproductive work and $39 \%$ did not have opportunities to be involved in patient assessment or clinical scenarios. [12] A qualitative study with 15 paramedic preceptors indicated there were differences between skills students obtained from classrooms and hands-on skills seen in ambulance services. They also believed that short placements limited students' learning opportunities, while extended periods of clinical practice with specific instructors for students would produce beneficial clinical experiences. [13] Unfortunately, the study did not measure the competencies and satisfaction students gained from placements. There are limited opportunities for clinical placements in Australia, so one university in Victoria took paramedic students for international clinical placement experiences in Israel.

When the clinical benefits of work experiences in traditional placements and Israeli ambulance services were compared, findings showed that caseloads between the two settings were not significantly different but students gained more experiences from the various shifts worked in Israeli ambulance services. [14]

It appears that most studies of paramedic clinical placements in Australia have been conducted in Victoria. Clinical experiences obtained from ambulance services in other states may be similar, but this study aimed to explore the relationship between paramedic preceptors' views of student competencies and student satisfaction with preceptors in clinical settings in the Ambulance Service of New South Wales, Australia.

\section{Methods}

This retrospective study used preceptors' assessments and student feedback forms collected in the Bachelor of Clinical Practice (Paramedic) course. Paramedic preceptors assessed the clinical skills and other competencies demonstrated by undergraduate paramedic students who undertook a four-week clinical placement in ambulance stations around New South Wales in their final year. The 233 students were divided into three groups for placement in February $(n=57)$, August $(n=83)$ or November $(n=93)$. Forms from 73 paramedic preceptors were incomplete, giving a total of 160 responses for analysis. Because this was a retrospective study, informed consent was not sought.

\section{Instruments}

Two self-report questionnaires were developed by one of the authors who has worked in ambulance services and educational settings for more than 20 years. Three lecturers from the university assessed the questionnaires for content validity and judged that they were suitable for the paramedic clinical placement paradigm.

\section{Preceptor evaluation of student competency}

Preceptors assessed student competency on 15 items divided into six main categories: survey on scene, monitoring and assessment, communication, clinical decision-making, 
functioning as a team member, and standard infection control precautions. Preceptors were asked to rate each item on a 4-point nominal scale, E (Exemplary), S (Satisfactory), $\mathrm{NI}$ (Needs Improvement), U (Unsatisfactory), and to report students' strengths and areas for improvement in two open-ended questions. Each student was assessed twice during placement, at the end of Week 2 and Week 4, and preceptors reported their assessments directly to a lecturer at the university. Internal consistency (Cronbach's alpha) was 0.921 .

\section{Student clinical placement feedback}

This was a self-administered 14-item tool for students to provide feedback for each ambulance service in which they undertook clinical placement, in four categories: preceptor's expertise (clinical skills, experiences and role modelling), supportive environment (orientation, staff welcoming, participation encouraged), constructive feedback (verbal and written), and attitude towards returning to placement venue. Each item was assessed on a 6-point Likert scale, Non-Applicable (1), Strongly Disagree (2), Disagree (3), Uncertain (4), Agree (5), and Strongly Agree (6). Two openended questions were used to assess what students found most valuable during the clinical placement, and what they liked least in the clinical placement. Students completed the feedback form at the end of the four-week placement and returned it to the university. In total, 21 forms were submitted. Internal consistency of this instrument was 0.849 .

\section{Data analysis}

Quantitative data. Descriptive statistics were used to analyse frequency counts and percentages. For the student feedback scale, total scores were summed from the 14 items and divided into quartiles. The 1st quartile was defined as 'to some extent satisfied', followed by 'satisfied' (Q2), 'very satisfied' (Q3), and 'extremely satisfied' (Q4). For preceptors' assessments, Wilcoxon's matched pairs signed ranks test was performed to compare the difference in competency for each student between the end of the second and fourth weeks of clinical placement. A $p$ value $<.05$ was used to indicate statistical significance. All analyses were performed using SPSS version 20.

\section{Content analysis}

Qualitative data (open-ended questions). Content analysis was used to analyse the openended questions on preceptor assessments and student feedback forms. This is an appropriate method for handling large amounts of data. [15] The researchers extracted key words and phrases from the open-ended responses, then allocated codes and developed categories and themes. The emergent codes and themes were discussed until agreement was reached to validate the findings. For instance, themes identified in preceptor evaluations were 'student competencies' and 'skills improvement', and categories included 'appropriate behaviour and professional socialisation', 'competency in clinical skills and keen to learn', 'lacking selfconfidence' 'communication difficulty', and 'shortage of case scenarios'.

\section{Results}

Preceptors submitted two complete reports for 160 students (40 in February, 60 in August, and 60 in November). Of these students, 88 (55\%) were male and 72 (45\%) female. The 73 incomplete assessments were excluded from the study. Most preceptors from 21 ambulance stations were male and their paramedic qualifications ranged from paramedic (P1) to paramedic specialists (Intensive Care Paramedic and Aviation Paramedic).

Preceptor evaluations of student competencies are shown in Table 1. Unsurprisingly, students showed improvement across all items between the assessments in Week 2 and Week 4. The differences were statistically significant. For the item 'conducting a primary survey' the percentage of students rated as 'Needs Improvement' fell significantly from $6.25 \%$ at Week 2 to $4.38 \%$ at Week 4, a reduction of $29.92 \%$. The improvement was more marked for the item 'establish rapport with patients', from $6.88 \%$ at Week 2 to $0.63 \%$ at Week 4 , a reduction of $90.84 \%$. The number of students rated as 'Needs Improvement' on any item at the end of Week 2 fell significantly by the end of Week 4. Similarly, the preceptor evaluations at 'Exemplary' level substantially increased to nearly $60 \%$ at Week 4 for the item'assess patient to formulate diagnosis', and by approximately $50 \%$ for the item 'conduct a secondary survey'. In addition, evaluations at 'Exemplary' level for the items about using communication skills to obtain information and using clinical decision-making to suggest appropriate care increased by almost $40 \%$ between the end of Week 2 and the end of Week 4.

Student perceptions are shown in Table 2. The majority of students acknowledged that clinical staff welcomed them and provided a supportive atmosphere, with approximately $72 \%$ strongly agreeing. Similarly, more than $71 \%$ strongly agreed that their preceptor had appropriate skills and experience and encouraged them to ask questions, helped them to engage in clinical experiences (61.90\%), and provided good verbal feedback on their progress (52.38\%). More than $50 \%$ of students agreed that they received appropriate direction when they first arrived and had 
Table 1. Preceptors' perceptions of student competencies during four-week placement

\begin{tabular}{|c|c|c|c|c|c|c|c|c|c|}
\hline \multirow[t]{2}{*}{ DETAILS } & \multicolumn{2}{|c|}{ EXEMPLARY } & \multicolumn{2}{|c|}{ SATISFACTORY } & \multicolumn{2}{|c|}{$\begin{array}{c}\text { NEEDS } \\
\text { IMPROVEMENT }\end{array}$} & \multicolumn{2}{|c|}{ UNSATISFACTORY } & \multirow[t]{2}{*}{ PVALUE } \\
\hline & $\begin{array}{l}\text { WK1 } \\
-2\end{array}$ & $\begin{array}{c}\text { WK3 } \\
-4\end{array}$ & $\begin{array}{l}\text { WK1 } \\
-2\end{array}$ & $\begin{array}{c}\text { WK3 } \\
-4\end{array}$ & $\begin{array}{l}\text { WK1 } \\
-2\end{array}$ & $\begin{array}{c}\text { WK3 } \\
4\end{array}$ & $\begin{array}{l}\text { WK1 } \\
-2\end{array}$ & $\begin{array}{c}\text { WK3 } \\
-4\end{array}$ & \\
\hline $\begin{array}{l}\text { Student's capacity to conduct a complete survey, identify and } \\
\text { minimise potential on-scene risks, maintain a safe working } \\
\text { environment. }\end{array}$ & $\begin{array}{c}26 \\
(16.25 \%)\end{array}$ & $\begin{array}{c}32 \\
(20 \%)\end{array}$ & $\begin{array}{c}115 \\
(71.88 \%)\end{array}$ & $\begin{array}{c}117 \\
(73.13 \%)\end{array}$ & $\begin{array}{c}19 \\
(11.88 \%)\end{array}$ & $\begin{array}{c}11 \\
(6.88 \%)\end{array}$ & - & - & $.03^{*}$ \\
\hline Student's ability in conducting a primary survey. & $\begin{array}{c}38 \\
(23.75 \%)\end{array}$ & $\begin{array}{c}62 \\
(38.75 \%)\end{array}$ & $\begin{array}{c}112 \\
(70 \%)\end{array}$ & $\begin{array}{c}91 \\
(56.88 \%)\end{array}$ & $\begin{array}{c}10 \\
(6.25 \%)\end{array}$ & $\begin{array}{c}7 \\
(4.38 \%)\end{array}$ & - & - & $.00^{*}$ \\
\hline $\begin{array}{l}\text { Student's ability to conduct secondary survey, incorporating } \\
\text { a systematic physical examination of the whole body. }\end{array}$ & $\begin{array}{c}29 \\
(18.13 \%)\end{array}$ & $\begin{array}{c}55 \\
(34.38 \%)\end{array}$ & $\begin{array}{c}109 \\
(68.13 \%)\end{array}$ & $\begin{array}{c}91 \\
(56.88 \%)\end{array}$ & $\begin{array}{c}32 \\
(13.75 \%)\end{array}$ & $\begin{array}{c}14 \\
(8.75 \%)\end{array}$ & - & - & $.00^{*}$ \\
\hline $\begin{array}{l}\text { Student's competencies in obtaining a history of the event } \\
\text { from the patient, carer and bystanders }\end{array}$ & $\begin{array}{c}39 \\
(24.38 \%)\end{array}$ & $\begin{array}{c}64 \\
(40 \%)\end{array}$ & $\begin{array}{c}90 \\
(56.25 \%)\end{array}$ & $\begin{array}{c}83 \\
(51.88 \%)\end{array}$ & $\begin{array}{c}31 \\
(19.38 \%)\end{array}$ & $\begin{array}{c}13 \\
(8.13 \%)\end{array}$ & - & - & $00^{*}$ \\
\hline $\begin{array}{l}\text { Student's ability in checking and monitoring a patient's vital } \\
\text { signs and repeated vital signs, e.g., SP, Pulse, ECG. }\end{array}$ & $\begin{array}{c}84 \\
(52.50 \%)\end{array}$ & $\begin{array}{c}111 \\
(69.38 \%)\end{array}$ & $\begin{array}{c}72 \\
(45.0 \%)\end{array}$ & $\begin{array}{c}48 \\
(30 \%)\end{array}$ & $\begin{array}{c}4 \\
(2.50 \%)\end{array}$ & $\begin{array}{c}1 \\
(0.63 \%)\end{array}$ & - & - & $00^{*}$ \\
\hline $\begin{array}{l}\text { Student's competence to undertake a patient assessment } \\
\text { to provisionally diagnose the patient's chief complaint. }\end{array}$ & $\begin{array}{c}21 \\
(13.13 \%)\end{array}$ & $\begin{array}{c}50 \\
(31.25 \%)\end{array}$ & $\begin{array}{c}109 \\
(68.13 \%)\end{array}$ & $\begin{array}{c}95 \\
(59.38 \%)\end{array}$ & $\begin{array}{c}30 \\
(18.75 \%)\end{array}$ & $\begin{array}{c}15 \\
(9.38 \%)\end{array}$ & - & - & $00^{*}$ \\
\hline $\begin{array}{l}\text { Student's ability to apply clinical problem solving processes } \\
\text { to both familiar and unfamiliar patient complaints. }\end{array}$ & $\begin{array}{c}22 \\
(13.75 \%)\end{array}$ & $\begin{array}{c}34 \\
(21.25 \%)\end{array}$ & $\begin{array}{c}102 \\
(63.75 \%)\end{array}$ & $\begin{array}{c}109 \\
(68.13 \%)\end{array}$ & $\begin{array}{c}36 \\
(22.50 \%)\end{array}$ & $\begin{array}{c}17 \\
(10.63 \%)\end{array}$ & - & - & $00^{*}$ \\
\hline $\begin{array}{l}\text { Student's proficiency to implement or suggest appropriate care } \\
\text { based on their patient assessment observations within the scope } \\
\text { of practice in accordance with ASNSW protocol/pharmacology. }\end{array}$ & $\begin{array}{c}26 \\
(16.25 \%)\end{array}$ & $\begin{array}{c}40 \\
(25 \%)\end{array}$ & $\begin{array}{c}101 \\
(63.13 \%)\end{array}$ & $\begin{array}{c}106 \\
(66.25 \%)\end{array}$ & $\begin{array}{c}33 \\
(20.63 \%)\end{array}$ & $\begin{array}{c}14 \\
(8.75 \%)\end{array}$ & - & - & $00^{*}$ \\
\hline $\begin{array}{l}\text { Student's ability to convey necessary information, using IMISTAMBO } \\
\text { format, to those health workers involved in the ongoing care } \\
\text { of their patients. }\end{array}$ & $\begin{array}{c}32 \\
(20 \%)\end{array}$ & $\begin{array}{c}52 \\
(32.50 \%)\end{array}$ & $\begin{array}{c}94 \\
(58.75 \%)\end{array}$ & $\begin{array}{c}96 \\
(60 \%)\end{array}$ & $\begin{array}{c}34 \\
(21.25 \%)\end{array}$ & $\begin{array}{c}12 \\
(7.50 \%)\end{array}$ & - & - & $00^{*}$ \\
\hline $\begin{array}{l}\text { Student aptitude to applying standard precautions to prevent } \\
\text { the spread of infection using PPE, and hand washing. }\end{array}$ & $\begin{array}{c}89 \\
(55.63 \%)\end{array}$ & $\begin{array}{c}109 \\
(68.13 \%)\end{array}$ & $\begin{array}{c}63 \\
(39.38 \%)\end{array}$ & $\begin{array}{c}51 \\
(31.88 \%)\end{array}$ & $\begin{array}{c}7 \\
(4.38 \%)\end{array}$ & - & $\begin{array}{c}1 \\
(0.63 \%)\end{array}$ & - & $00^{*}$ \\
\hline $\begin{array}{l}\text { The student's ability to perform pre-shift ambulance vehicle } \\
\text { roadworthiness check. Ensure that vehicle is properly equipped } \\
\text { and supplied after each case. Ensure vehicle is maintained in } \\
\text { a clean, aseptic manner. }\end{array}$ & $\begin{array}{c}85 \\
(53.13 \%)\end{array}$ & $\begin{array}{c}108 \\
(67.50 \%)\end{array}$ & $\begin{array}{c}71 \\
(44.38 \%)\end{array}$ & $\begin{array}{c}50 \\
(31.25 \%)\end{array}$ & $\begin{array}{c}4 \\
(2.50 \%)\end{array}$ & $\begin{array}{c}1 \\
(0.63 \%)\end{array}$ & - & $\begin{array}{c}1 \\
(0.63 \%)\end{array}$ & $00^{*}$ \\
\hline $\begin{array}{l}\text { The student's proficiency to communicate clear and direct } \\
\text { instructions. }\end{array}$ & $\begin{array}{c}49 \\
(30.63 \%)\end{array}$ & $\begin{array}{c}78 \\
(48.75 \%)\end{array}$ & $\begin{array}{c}100 \\
(62.50 \%)\end{array}$ & $\begin{array}{c}77 \\
(48.13 \%)\end{array}$ & $\begin{array}{c}11 \\
(6.88 \%)\end{array}$ & $\begin{array}{c}5 \\
(3.13 \%)\end{array}$ & - & - & $00^{*}$ \\
\hline $\begin{array}{l}\text { The student's ability to introduce themselves and ask questions } \\
\text { and clarify information from patients. }\end{array}$ & $\begin{array}{c}70 \\
(43.75 \%)\end{array}$ & $\begin{array}{c}92 \\
(57.50 \%)\end{array}$ & $\begin{array}{c}72 \\
(45 \%)\end{array}$ & $\begin{array}{c}64 \\
(40 \%)\end{array}$ & $\begin{array}{c}18 \\
(11.25 \%)\end{array}$ & $\begin{array}{c}4 \\
(2.50 \%)\end{array}$ & - & - & $00^{*}$ \\
\hline $\begin{array}{l}\text { Establish a rapport with patient by displaying an open, sensitive } \\
\text { and confident manner. }\end{array}$ & $\begin{array}{c}84 \\
(52.50 \%)\end{array}$ & $\begin{array}{c}110 \\
(68.75 \%)\end{array}$ & $\begin{array}{c}65 \\
(40.63 \%)\end{array}$ & $\begin{array}{c}49 \\
(30.63 \%)\end{array}$ & $\begin{array}{c}11 \\
(6.88 \%)\end{array}$ & $\begin{array}{c}1 \\
(0.63 \%)\end{array}$ & - & - & $00^{*}$ \\
\hline Student's capacity to function as a team member & $\begin{array}{c}104 \\
(65 \%)\end{array}$ & $\begin{array}{c}125 \\
(78.13 \%)\end{array}$ & $\begin{array}{c}51 \\
(31.88 \%)\end{array}$ & $\begin{array}{c}33 \\
(20.63 \%)\end{array}$ & $\begin{array}{c}5 \\
(3.13 \%)\end{array}$ & $\begin{array}{c}1 \\
(0.63 \%)\end{array}$ & - & $\begin{array}{c}1 \\
(0.63 \%)\end{array}$ & $00^{*}$ \\
\hline
\end{tabular}

${ }^{*} \mathrm{p}<.05$ 
sufficient orientation to the workplace. Students were less satisfied with communication about rostering, with $9.52 \%$ disagreeing and $4.76 \%$ strongly disagreeing that this was adequate. Approximately $50 \%$ of students were satisfied with the placement, with $9.52 \%$ being very satisfied and $19.05 \%$ being extremely satisfied.

\section{Qualitative results}

\section{Student competency}

Appropriate behaviour and professional socialisation

Students who demonstrated appropriate behaviour and professional socialisation to clinical staff helped create a positive atmosphere and harmony within the workplace.

Table 2. Students' Perceptions of Clinical Placement

\begin{tabular}{|c|c|c|c|c|c|c|}
\hline ITEM & $\begin{array}{l}\text { STRONGLY } \\
\text { AGREE }\end{array}$ & AGREE & UNCERTAIN & $\begin{array}{l}\text { DISAGREE } \\
\text { DISAGREE }\end{array}$ & STRONGLY & N/A \\
\hline $\begin{array}{l}\text { I received appropriate direction when I first arrived to undertake } \\
\text { the clinical placement. }\end{array}$ & $\begin{array}{c}9 \\
(42.86 \%)\end{array}$ & $\begin{array}{c}11 \\
(52.38 \%)\end{array}$ & $\begin{array}{c}1 \\
(4.76 \%)\end{array}$ & - & - & - \\
\hline My orientation to the workplace was sufficient. & $\begin{array}{c}9 \\
(42.86 \%)\end{array}$ & $\begin{array}{c}12 \\
(57.14 \%)\end{array}$ & - & - & - & - \\
\hline $\begin{array}{l}\text { Communication regarding the roster I was required to work during } \\
\text { the placement was adequate. }\end{array}$ & $\begin{array}{c}8 \\
(38.10 \%)\end{array}$ & $\begin{array}{c}7 \\
(33.33 \%)\end{array}$ & $\begin{array}{c}3 \\
(14.29 \%)\end{array}$ & $\begin{array}{c}2 \\
(9.52 \%)\end{array}$ & $\begin{array}{c}1 \\
(4.76 \%)\end{array}$ & - \\
\hline $\begin{array}{l}\text { The majority of the clinical staff and other colleagues I worked } \\
\text { with during the placement made me feel welcome. }\end{array}$ & $\begin{array}{c}15 \\
(71.43 \%)\end{array}$ & $\begin{array}{c}6 \\
(28.57 \%)\end{array}$ & - & - & - & - \\
\hline $\begin{array}{l}\text { The majority of the clinical staff and other colleagues I worked with } \\
\text { during the placement were both approachable and supportive. }\end{array}$ & $\begin{array}{c}15 \\
(71.43 \%)\end{array}$ & $\begin{array}{c}6 \\
(28.57 \%)\end{array}$ & - & - & - & - \\
\hline $\begin{array}{l}\text { The majority of the clinical staff and other colleagues I worked with } \\
\text { were good paramedic role models }\end{array}$ & $\begin{array}{c}11 \\
(52.38 \%)\end{array}$ & $\begin{array}{c}10 \\
(47.62 \%)\end{array}$ & - & - & - & - \\
\hline $\begin{array}{l}\text { My clinical preceptor had the experience necessary to supervise } \\
\text { my placement opportunity. }\end{array}$ & $\begin{array}{c}15 \\
(71.43 \%)\end{array}$ & $\begin{array}{c}5 \\
(23.81 \%)\end{array}$ & $\begin{array}{c}1 \\
(4.76 \%)\end{array}$ & - & - & - \\
\hline $\begin{array}{l}\text { My clinical preceptor had the skill necessary to supervise my } \\
\text { placement opportunity. }\end{array}$ & $\begin{array}{c}14 \\
(66.67 \%)\end{array}$ & $\begin{array}{c}6 \\
(28.57 \%)\end{array}$ & $\begin{array}{c}1 \\
(4.76 \%)\end{array}$ & - & - & - \\
\hline My clinical preceptor encouraged me to ask questions. & $\begin{array}{c}15 \\
(71.43 \%)\end{array}$ & $\begin{array}{c}4 \\
(19.05 \%)\end{array}$ & $\begin{array}{c}1 \\
(4.76 \%) 1\end{array}$ & $\begin{array}{c}1 \\
(4.76 \%)\end{array}$ & - & - \\
\hline $\begin{array}{l}\text { My clinical preceptor or other colleagues helped me to identify } \\
\text { and engage in appropriate learning experiences. }\end{array}$ & $\begin{array}{c}13 \\
(61.90 \%)\end{array}$ & $\begin{array}{c}6 \\
(28.57 \%)\end{array}$ & $\begin{array}{c}2 \\
(9.52 \%)\end{array}$ & - & - & - \\
\hline I was able to apply what I learnt at university on clinical placement. & $\begin{array}{c}8 \\
(38.10 \%)\end{array}$ & $\begin{array}{c}12 \\
(57.14 \%)\end{array}$ & $\begin{array}{c}1 \\
(4.76 \%)\end{array}$ & - & - & - \\
\hline $\begin{array}{l}\text { Verbal feedback received while I was on placement gave me a good } \\
\text { idea on how I was progressing. }\end{array}$ & $\begin{array}{c}11 \\
(52.38 \%)\end{array}$ & $\begin{array}{c}6 \\
(28.57 \%)\end{array}$ & $\begin{array}{c}3 \\
(14.29 \%)\end{array}$ & $\begin{array}{c}1 \\
(4.76 \%)\end{array}$ & - & - \\
\hline $\begin{array}{l}\text { Written feedback from the preceptor received during the placement } \\
\text { gave me a good idea on how was progressing. }\end{array}$ & $\begin{array}{c}7 \\
(33.33 \%)\end{array}$ & $\begin{array}{c}10 \\
(47.62 \%)\end{array}$ & - & $\begin{array}{c}3 \\
(9.52 \%)\end{array}$ & - & $\begin{array}{c}2 \\
(9.52 \%)\end{array}$ \\
\hline $\begin{array}{l}\text { I would like to return to this workplace again to complete more } \\
\text { clinical training. }\end{array}$ & $\begin{array}{c}12 \\
(57.14 \%)\end{array}$ & $\begin{array}{c}4 \\
(19.05 \%)\end{array}$ & $\begin{array}{c}3 \\
(14.29 \%)\end{array}$ & $\begin{array}{c}2 \\
(9.52 \%)\end{array}$ & - & - \\
\hline \multicolumn{7}{|l|}{ Total Student Perception of clinical placement } \\
\hline To some extent satisfied & 1st quartile & 5 & $23.18 \%$ & & & \\
\hline Satisfied & 2nd quartile & 10 & $47.62 \%$ & & & \\
\hline Very satisfied & 3rd quartile & 2 & $9.52 \%$ & & & \\
\hline Extremely satisfied & 4th quartile & 4 & $19.05 \%$ & & & \\
\hline
\end{tabular}


Therefore, preceptors were willing to teach clinical skills and answer students' questions when they required clarification.

Preceptor A: Student A is a very happy person and easy to get along with. She engages with staff and patients well. She follows instruction well and is learning quickly. A pleasure to be mentoring. The areas that need improvement are getting better as she gains experience. She is doing well for the time she has spent on road.

Preceptor D: Student D is a polite and courteous student who works well in a team environment. He actively seeks clarification on anything he may not understand. He demonstrates a willingness to learn. He gives a concise and accurate patient handover to other medical staff.

\section{Competency in clinical skills and keen to learn}

Paramedic students showed a high level of clinical knowledge and understood how to integrate theoretical knowledge into practice. They were actively involved in assessment and treatment of patients, and were keen to learn in different environments.

Preceptor B: Student B has shown an above average ability to apply clinical knowledge to on road experiences. He is mature for his age and this is apparent when dealing with patients. I believe his life experiences prior to University with safety have placed him well for paramedicine. He is patient, displays empathy, and is keen and quick at adapting to ever-changing environments...

Preceptor C: Within the first two weeks of student C's placement he has immediately applied himself to all tasks asked of him. He has been punctual for every shift and... He has been well presented and courteous to all staff members and allied health professionals. He is extremely keen to actively participate in the assessment and treatment of all patients, regardless of the patient complaint, and he seeks guidance when required...

\section{Required improvements}

\section{Lack of self-confidence}

Preceptors identified areas where students needed to make improvement. These included development of greater selfconfidence and assertive communication skills to enable them to manage challenging situations.

Preceptor B: Student B needs to be more forward/ confident in talking with patients to ensure he has an accurate history of the events leading up to pt/paramedic meeting-I know this will be well addressed in the near future. With more on-road time, I believe he will be a solid clinician and will make a very good paramedic, welcomed on any station within ASNSW.
Preceptor G: On the flip side of above, she will need to learn to be assertive in difficult and confronting situations.

\section{Communication difficulties}

Students were sometimes nervous when asking for patient information or investigating the circumstances surrounding a call-out. This was apparent from their low-pitched voices when participating in patient assessments. Paramedics are the first healthcare personnel on the scene in emergencies, so clear communication and assertive behaviour is essential for them to gather crucial information from patients and eyewitnesses before giving treatment.

Preceptor A: Student A can be shy at times when dealing with patients and families and just needs to find some more confidence and initiative to fulfil some of these requirements. Student does need to be asked if she would like to train in anything or if she has any questions regarding jobs. She could be a bit more forward in wanting to participate in practical training sessions.

Preceptor D: Encouraging student $D$ to be more assertive and direct when trying to obtain a patient history. I have explained to him that he needs to increase the volume of his voice when talking to patients as they have difficulty hearing him.

\section{Limited case scenarios}

Students placed in regional areas with limited case scenarios missed the learning opportunities that arise when dealing with a diverse range of cases. Nevertheless, when exposed to a trauma scene, students showed competency for managing situations, including leadership and suggested treatment pathways.

Preceptor E: The only areas of improvement I can see for student are to be exposed to real life scenarios to give her experience and a greater depth of knowledge.

Preceptor F: Unfortunately to this point we have had limited exposure to some skills such as trauma requiring IMISTAMBO and scene reports. There have also been limited opportunities to cannulate and set up fluids. On the occasions that this has occurred she has performed these tasks with little problem.... She has shown constant improvement in her confidence and I am sure by the end of the 4 weeks together her ability to show leadership and control scenes will have reached the level expected of her.

\section{Students' feedback}

\section{Effectiveness of preceptors}

Students appreciated preceptors who allowed them to have a range of clinical experiences and use their knowledge on 
real patients. Students also enjoyed working with preceptors who were easy to relate to and who helped them to keep calm.

Student $K$ : That my preceptor was so approachable and an excellent teacher. Let me get involved in everything and I would highly suggest him to have another student. I also found very valuable that not every call is an emergency and every job is different.

Student M: My preceptors were very easy to work with and they were more than happy to let me use my skills and training on patients. If I had any questions or concerns my preceptors were very approachable and gave vital feedback.

\section{Exposure to real-life experiences and improvement in clinical skills}

Students gained greater understanding of how to perform ambulance tasks and work effectively with patients and other healthcare professionals when they were exposed to reallife situations. These enabled them to apply the knowledge acquired at university to practical scenarios.

Student I: I feel that my hand-overs to triage nurses and doctors improved a lot over the 3 weeks and by the third week I was presenting all hand-overs.

Student J: Getting real practical experience!!! My preceptor was very knowledgeable and able to explain the pathophysiology of everything! Learning how ambos work together and where everything is placed in the ambulance was great! Also, skills for questioning difficult patients! And just treating actual people!

\section{Shortage of case experiences}

Students were not pleased when their placement venues offered only a limited range of learning experiences in reallife ambulance settings. They believed this restricted their learning experiences and opportunities to put theoretical knowledge into practice in prehospital situations. They felt bored and untested when dealing only with non-emergency calls and light case loads.

Student L: Placement in rural areas didn't provide me with the load or work or experience I was hoping to see.

Student I: Because the area I was in wasn't very busy I feel like I didn't really receive anything too exciting nor challenging. The one call out that I found exciting because I'd learnt so much about it, I was put in the front seat and didn't really even get talked through it.

\section{Discussion}

In the study, paramedic students showed satisfactory to exemplary levels of competencies in their clinical skills, and preceptor evaluations of student abilities increased between the first and second assessments for all items. A similar picture was seen in the qualitative data, with preceptors reporting that students were skilled at putting their theoretical knowledge into practice and that they displayed appropriate behaviour and professional socialisation when working with staff and patients. Preceptors were willing to teach students and allow them to undertake clinical experiences in real-life scenarios especially where there were good working relationships between themselves and students. These findings differed from those in a qualitative study by O'Meara and colleagues, who found that preceptors from vocational backgrounds tended to limit students to observation only rather than allowing them hands-on clinical practices, while preceptors who were university-educated paramedics adopted the opposite view. [13] Several studies have pointed out that building a healthy relationship is the key in achieving satisfactory learning experiences in clinical placements. Through this, preceptors can encourage students' exposure to clinical skills, improve their self-confidence and enhance their critical thinking. [16-18] A paramedic clinical placement study in Victoria demonstrated that paramedic students expressed concern about their experiences on clinical placements. The findings showed nearly $60 \%$ of students had negative experiences with preceptors, such as 'being ignored' and 'know nothing but not offered any opportunities to practice skills. [12] A mutual relationship in the preceptorship whereby staff accept students as team members, take care of them, show empathy and act as good role models is the most effective strategy to achieve student learning in clinical practice. [16] In this study, findings from the qualitative data clearly show the benefits for students who experienced a sense of security through building good personal relationships with the preceptor and other staff.

These students showed an increasing trust in their own abilities as they participated in challenging activities, they were not afraid to ask questions and started to work independently.

The findings also demonstrated that students' competencies increased significantly across most skill categories in the final weeks of placement. Consistent, long-term exposure to reallife scenarios helped to boost students' selfconfidence, allowing them to take the initiative to perform complicated tasks. Conversely, short periods of placement 
limited students' learning opportunities to practise clinical skills while creating difficulties for ambulance settings in organising shifts and seeking mentors. [13] Students who experienced different emergency scenarios and who were able to stay longer on scene gained more experience of clinical procedures and reported high satisfaction levels. Similarly, McCall et al (2009) indicated that students' learning experiences depended on the caseload in the services where they undertook placement. Students gained a wider range of experiences when undertaking placement in metropolitan areas rather than with rural ambulance services. [19] The development of professional competency in pre-hospital settings usually depends upon exposure to a diversity of caseload scenarios and the use of effective clinical decisionmaking skills acquired during clinical placements. Clinical placements that function well are influential in enhancing learning and generating professional identity for paramedic students. The study showed that the students' level of knowledge before placement was sufficient for them to manage the reallife scenarios they encountered. However, they needed to develop more self-confidence and assertive communication skills so they could adapt quickly to new environments and reduce possible dissatisfaction between students and supervisors. Sustained cooperation between universities and ambulance services is essential to provide a good learning atmosphere for students and reduce frustration among clinical staff.

\section{Limitations of the study}

The use of existing data in this retrospective study potentially created bias because it was not possible to confirm or reassess information, while some crucial variables were missing and there were issues with data quality and generalisability. A strength of the study is that it reports new findings about the development of mutual relationships between preceptors and paramedic students and the value of increasing the length of clinical placement periods, both of which could lead to improved quality of clinical placements. These findings have not been identified previously, nor have there been studies conducted in New South Wales, Australia.

\section{Funding}

There is no funding support for the study.

\section{Competing Interests}

The authors declare that they have no competing interests.

\section{References}

1. Hyrkas K, Shoemaker M. Changes in the preceptor role: re-visiting preceptors' perceptions of benefits, rewards, support and commitment to the role. J Adv Nurs. 2007;60:513-522.

2. Kemper N. Win-win strategies help relieve preceptor burden. Nurs Manag. 2007; 38:10-12.

3. Hautala KT, Saylor CR, O'Leary-Kelley C. Nurses' perceptions of stress and support in the preceptor role. J Nurses Staff Dev. 2007;23 64-70.

4. Bradbury-Jones C, Sambrook S, Irvine F. The meaning of empowerment for nursing students: a critical incident study. J Adv Nurs. 2007;59:342-351.

5. Myrick F, Phelan A, Barlow C, et al. Conflict in the preceptorship or field experience: a rippling tide of silence. Int J Nurs Educ Scholarsh. 2006;3:1-14.

6. Billay D, Myrick F. Preceptorship: an integrative review of the literature. Nurse Educ Pract. 2008;8:258-266.

7. Pittet V, Burnand B, Yersin B, Carron P-N. Trends of pre-hospital emergency medical services activity over 10 years: a populationbased registry analysis. BMC Health Serv Res. 2014;14:380.

8. Talib F, Rahman Z, Azam M. Best practices of total quality management implementation in health care settings. Health Mark Q. 2011;28:32-252.

9. Hou XY, Rego J, Service M. Review article: Paramedic education opportunities and challenges in Australia. Emerg Med Australas. 2013;25:114-119.

10. Burgess S, Boyle M, Chilton M et al. Monash University Centre for Ambulance and Paramedic Studies (MUCAPS) Submission to the Department of Human Services (DHS), in response to the DHS Discussion Paper examining the regulation of the Health Professions in Victoria. Emergency Primary Health Care. 2003;1:3-4.

11. Trede F, McEwen C, O'Meara P. Supervisors' experiences of workplace supervision of nursing and paramedic students in rural settings: A scoping review. Nurse Educ Today. 2014; 4:783-788.

12. Boyle MJ, Williams B, Cooper J et al. Ambulance clinical placementsa pilot study of students' experience. BMC Med Educ. 2008;8:19.

13. O'Meara P, Williams B, Hickson $H$. Paramedic instructor perspectives on the quality of clinical and field placements for university educated paramedicine students. Nurse Educ Today. 2015;35: 1080-1084.

14. Smith G. Examination of undergraduate paramedic clinical placement within a traditional and novel setting. Australasian Journal of Paramedicine. 2016;13(4):1-7.

15. Shuyler KS, Knight KM. What are patients seeking when they turn to the internet? Qualitative content analysis of questions asked by visitors to an orthopaedics Web site. Journal of Medicine Internet Research. 2003;5:e24.

16. Wallin K, Fridlund B, Thoren AB. Prehospital Emergency Nursing students' experiences of learning during prehospital clinical placements. Int Emerg Nurs. 2013;21:197-203.

17. Webb C, Shakespeare P. Judgements about mentoring relationships in nurse education. Nurse Educ Today. 2008;28:563-571.

18. Newton JM, Billett S, Ockerby C. Journey through clinical placements - an examination of six student cases. Nurse Educ Today. 2009;29:630-634.

19. McCall L, Wray N, Lord B. Factors affecting the education of preemployment paramedic students during the clinical practicum. Journal of Emergency Primary Health Care. 2009;7:Article990334. 